Int. J. Odontostomat., 10(2):297-302, 2016.

\title{
Knowledge and Attitudes of Pregnant Women About Oral Health
}

\author{
Conocimientos y Actitudes de las Mujeres Embarazadas sobre la Salud Oral
}

\author{
Brenna Magdalena Lima Nogueira*; Bárbara Catarina Lima Nogueira*; \\ Ricardo Roberto de Souza Fonseca ${ }^{* * *}$; Gustavo Antônio Martins Brandão ${ }^{* \star * *}$; \\ Tatiany Oliveira de Alencar Menezes ${ }^{* * * * *}$ \& Dinair Pamplona dos Santos Tembra
}

NOGUEIRA, B. M. L.; NOGUEIRA, B. C. L.; FONSECA, R. R. S.; BRANDÃO, G. A. M.; MENEZES, T. O. A. \& TEMBRA, D. P. S. Knowledge and attitudes of pregnant women about oral health. Int. J. Odontostomat., 10(2):297-302, 2016.

ABSTRACT: There are evidences that maternal profile, habits and health knowledge, influence in the oral health of children. The aim of this study was to assess pregnant women knowledge on oral hygiene practices and maintenance of Baby's oral cavity. A descriptive epidemiological survey was conducted with 147 pregnant women. Sample was predominantly formed by young women and $33.33 \%$ had incomplete primary education and most were housewives with family income between 1-2 minimum wages. Family was considered the primary means in the transfer of information about oral hygiene.

KEY WORDS: pregnant women, oral hygiene, infant.

\section{INTRODUCTION}

Current tendencies of dental attention indicate that the model should be aimed at health promotion and prevention in order to reduce the curative procedures. Such idea has taken large space in the scientific community. However, what is observed is that most of the means used for prevention of oral diseases is aimed at people who have already acquired the disease, in other words, with little emphasis on early prevention (Kurien et al., 2013; Patil et al., 2013).

Pregnant women should be careful to look for Doctor of Dental Surgery (DDS) during pregnancy, not only for treatment of the problems presented by them, but to get information about the oral health of their child (Geisinger et al., 2013). Thus, the DDS must be inserted in the family health strategy, ensuring dental care during the prenatal period.

The pregnancy is pointed as the right time for preventive activities being absorbed because parents are more likely to learn and perform health care and pass to the child even at the tender age understand the important aspects regarding oral hygiene, creating favorable habits (Geisinger et al.; Shamsi et al., 2013; Figueiredo \& Brião, 2014). It is up to the DDS develop educational and preventive methods for the first six months of the newborn's life. It is in this period that there is greater possibility of involving parents as to the guidance on hygiene methods and harmful habits for oral health (Yost \& Li, 2008; Brião, 2014).

It is necessary, first of all, that the information to be passed as clear and concise manner so as to meet the target audience. Sociocultural differences are fundamental factors in the learning process. Often the problem for not obeying the rules is due to poor living conditions than an alleged unwillingness to follow them (George et al., 2010; Kurien et al.; Patil et al.).

There are evidences that maternal profile, habits and health knowledge, influence the oral health of the child. Therefore, the aim of this study was to analyze

\footnotetext{
Endodontics department, Graduate Program in Clinical Dentistry, Faculty of Dentistry, Federal University of Pará, Belém, Brazil.

** Dentistic department, Graduate Program in Clinical Dentistry, Faculty of Dentistry, Federal University of Pará, Belém, Brazil.

*** Graduate in Dentistry, Pará State University Center, Belém, Brazil.

Department of Public Health, Faculty of Dentistry, Federal University of Pará, Belém, Brazil.

Department Patients with Special Needs, School of Dentistry, Federal University of Pará, Belém, Brazil.

******* Institute of Biological Sciences, Federal University of Pará, Belém, Brazil.
} 
the knowledge of a group of women on oral hygiene practices and maintenance of the oral cavity baby during pregnancy.

\section{MATERIAL AND METHOD}

This research has fully complied with the ethical requirements was approved by the Committee, report $n^{\circ}$ 091/11, according to Resolution 196/96 of the National Health Council.

A quantitative / qualitative descriptive crosssectional study was conducted at the Santa Casa de Misericordia in Bethlehem, PA, Eastern Amazon, Brazil. The sample inclusion criteria were: all pregnant women, regardless of age, financial status, social class or ethnic group and that absenteeism to participate and those who refused being excluded.

For data collection we observe the health of oral hygiene practices and important information for maintaining the same health that pregnant women had before their pregnancy and knowledge about baby oral hygiene practices. This way, a closed and structured questionnaire was composed with 16 objective questions divided into three parts: socio-economic information, information regarding oral health of pregnant women and questions concerning the knowledge of oral health of the baby. The final sample consisted of 147 pregnant women.

The analysis was performed descriptively with the help of Microsoft Excel 2010 / Windows 7. The program results are explained and discussed in paragraphs that follow.

\section{RESULTS}

Table I describes the socio-economic data collected in the survey. It can be observed that 50.34 $\%$ of the pregnant women were in the age group between 12-22 years. The prevailing education level was incomplete elementary school with $33.33 \%$, with most of them housewives $(40.81 \%)$. With regard to family income, $65.30 \%$ of the women reported having income between 1 and 2 times the minimum wage. The prevalence of women between the first and second pregnancy was $74.14 \%$. The prevalence of women between the seventh and ninth month was $63.94 \%$.

Table I. Socioeconomic information of the group of pregnant women evaluated.

\begin{tabular}{|c|c|c|c|}
\hline Variable & & $\mathbf{n}$ & $\%$ \\
\hline Age & $12-22$ years & 74 & $50.34 \%$ \\
\hline & $23-32$ years & 54 & $36.73 \%$ \\
\hline & $33-42$ years & 19 & $12.92 \%$ \\
\hline Level of education & Illiterate & 3 & $2.04 \%$ \\
\hline & Elementary School Inc. & 49 & $33.33 \%$ \\
\hline & Elementary School Comp. & 19 & $12.92 \%$ \\
\hline & High School Inc. & 33 & $22.44 \%$ \\
\hline & High School Comp. & 40 & $27.21 \%$ \\
\hline & Higher Education Inc. & 2 & $1.36 \%$ \\
\hline & Higher Education Comp. & 1 & $0.68 \%$ \\
\hline Occupation & Unemployed & 48 & $32.65 \%$ \\
\hline & Employed & 39 & $26.53 \%$ \\
\hline & Housewivves & 60 & $40.81 \%$ \\
\hline Family Income & Less than 1 salary & 40 & $27.21 \%$ \\
\hline & $1-2$ salary & 96 & $65.30 \%$ \\
\hline & Over than 3 salary & 11 & $7.48 \%$ \\
\hline Number of Pregnancies & $1^{\text {st }}$ or $2^{\text {nd }}$ & 109 & $74.14 \%$ \\
\hline & $3^{\text {rd }}$ or $4^{\text {th }}$ & 29 & $19.72 \%$ \\
\hline & $5^{\ln U_{r} 6^{\text {nn }}}$ & 7 & $4.76 \%$ \\
\hline & $7^{\text {th }}$ & 2 & $1.36 \%$ \\
\hline Period of Gestation & $1-3$ months & 25 & $17 \%$ \\
\hline & 4-6 months & 28 & $19.04 \%$ \\
\hline & 7-9 months & 94 & $63.94 \%$ \\
\hline
\end{tabular}


Table II contains information regarding oral hygiene for pregnant women and providing care for them to maintain oral health. $80.95 \%$ did not attend dental clinic during pregnancy and $75.51 \%$ of pregnant women reported not having attendance in the dental office. Regarding the daily attention $94.55 \%$ brush their teeth every day, and $75.51 \%$ do so always after consuming some type of food. When asked about the person who had the greatest influence on their oral hygiene, the family was the most prevalent answer from the options (84.35\%). 93.19\% asserted the importance of care with hygiene during pregnancy.

Table III exposes the collection of results regarding to knowledge and ability of pregnant women in health maintenance and prevention of certain diseases in relation to the baby. When asked about the period to obtain relevant information to the oral health of the baby, $77.55 \%$ of pregnant women were unable to specify when. $72.78 \%$ of respondents say

Table II. Information relating to the care of Oral Health of Pregnant Women.

\begin{tabular}{llrr}
\hline Variables & & $\mathbf{n}$ & $\mathbf{\%}$ \\
\hline Frequence in dental office during pregnancy & Yes & 28 & 19.04 \\
& No & 119 & 80.95 \\
Visits to the dentist regularly & Yes & 36 & 24.48 \\
& No & 111 & 75.51 \\
Brush the teeth every day & Yes & 139 & 94.55 \\
Frequence of brushing & No & 8 & 5.44 \\
& Always after eating & 111 & 75.51 \\
& Only when wakes & 7.76 \\
Who has the greatest influence on Oral Hygiene & Upon waking and before bed & 29 & 19.72 \\
& Family & 124 & 84.35 \\
& Friends & 12 & 8.16 \\
Care during pregnancy & Dentist & 2 & 1.36 \\
& School & 9.12 \\
& Yes & 137 & 93.19 \\
& No & 10 & 6.80 \\
\hline
\end{tabular}

Table III. Information as to the attention of pregnant women concerning Baby Oral Health.

\begin{tabular}{|c|c|c|c|}
\hline Variables & & $\mathbf{n}$ & $\%$ \\
\hline \multirow[t]{2}{*}{ Know when obtain information about the Oral Health Baby } & Yes & 33 & 22.44 \\
\hline & No & 114 & 77.55 \\
\hline \multirow[t]{2}{*}{ Know the importance of breastfeeding } & Yes & 107 & 72.78 \\
\hline & No & 40 & 27.21 \\
\hline \multirow[t]{2}{*}{ Know how to sanitize the mouth of the baby after breastf eeding } & Yes & 59 & 40.13 \\
\hline & No & 88 & 59.86 \\
\hline \multirow[t]{2}{*}{ Procedures and precautions to be taken when the eruption of the first tooth } & Yes & 62 & 42.17 \\
\hline & No & 85 & 57.82 \\
\hline \multirow[t]{2}{*}{ Know the consequeces of eating sugar } & Yes & 62 & 42.17 \\
\hline & No & 85 & 57.82 \\
\hline \multirow[t]{2}{*}{ Know the benefits of fluorine } & Yes & 33 & 22.44 \\
\hline & No & 114 & 77.55 \\
\hline \multirow[t]{2}{*}{ Know the harms of fluorine } & Yes & 18 & 12.24 \\
\hline & No & 129 & 87.75 \\
\hline \multirow[t]{5}{*}{ Attitudes to cool the food } & Blow & 28 & 19.04 \\
\hline & Shakers and Fans & 12 & 8.16 \\
\hline & Cooling naturaling & 88 & 59.86 \\
\hline & Using the spoon & 7 & 4.76 \\
\hline & Bain marie & 12 & 8.16 \\
\hline \multirow[t]{2}{*}{ To kiss face, lips and/or hands } & Yes & 89 & 60.54 \\
\hline & No & 58 & 39.45 \\
\hline \multirow[t]{2}{*}{ Know to instruct the baby about oral hygiene } & Yes & 129 & 87.75 \\
\hline & No & 18 & 12.24 \\
\hline
\end{tabular}


they know the importance of breastfeeding, while $59.86 \%$ do not know how to sanitize the mouth of the child after breastfeeding.

$57.82 \%$ of pregnant women have no knowledge about the procedures and precautions that should be immediately dismissed after the eruption of the first tooth. The same percentage was observed when asked about the consequences caused by careless intake of sugar. $77.55 \%$ and $87.75 \%$ reported not to have knowledge regarding the benefits and harms - when used in excessive doses - fluoride, respectively.

The actions taken regarding the act to cool the food $59.86 \%$ of women ensured waiting for food to cool naturally. $60.54 \%$ reported kissing face, lips and / or baby's hands. $87.75 \%$ of the women said they would know to instruct their children about having and maintaining oral health.

\section{DISCUSSION}

The percentages obtained reveal that $50.34 \%$ of respondents were aged 12 to 22 years, followed by $36.73 \%$ of women between $23-32$ years. Thereby, these results point to a group of predominantly young mothers, so they are more likely to learn and be more aware with regard to attitudes towards health of their children (Gaffield et al., 2001; George et al., 2010).

In the last decades, social condition has been highlighted as important determinant of oral situation. In some studies it was observed that the largest numbers of children with high severity caries belonged to lower income families. Therefore, income is presented as a risk factor for high severity of dental caries (Schou \& Uitenbroek, 1995; Campos et al., 2010; Eigbobo \& Onyeaso, 2013). Considering the data found in this study, we can infer the need for understanding of the factors involved in health disease, related to oral health in young pregnant women.

It was observed that $65.30 \%$ of women had incomes between 1-2 minimum wages and $27.21 \%$ had one wage or less for living expenses. The literature asserts that the socioeconomic factor is an important point of access to information; the higher the socioeconomic level, higher is the care given to the oral health of children, there is a greater accumulation of knowledge and greater motivation to practice healthy behavior on the mother's part
(Keirse \& Plutzer, 2010; Ramos et al., 2014). The development of diseases such as caries and periodontal disease is associated with social, economic, political and educational, not just the result of biological interactions in the oral environment (Saddki et al., 2010).

Studies show that the type of occupancy of the household, as well as income and education have been linked to the degree of severity of dental caries (Schou \& Uitenbroek; de Oliveira \& Nadanovsky, 2006; Campos et al.; Eigbobo \& Onyeaso). The more unfavorable socioeconomic status, the greater the number of teeth affected by caries and the greater their severity. According to the results obtained 33.33 $\%$ of the women had not finished elementary school as educational level and $40.81 \%$ were housewives.

In the case of child health promotion, the methods used by mothers when it comes to oral health care of their children are essential. The child spends his first years of life and gets part of their social, cultural and educational backgrounds with family. Members have, create and transmit beliefs, values, knowledge and health practices. Historically, the mother figure is a prominent role in the health care of children; often she is responsible for the establishment of hygiene routines (Strafford et al., 2008; Morgan et al., 2009). According to the data collected, it was observed $84.35 \%$ of pregnant women experience major influence of family environment regarding oral hygiene habits, it being the most important means of spreading basic information for the maintenance of oral health. This information shows that the family is the most effective means for conducting certain practices, whether right or wrong (Costa et al., 2012; George et al., 2013).

The family members need to pay attention to their own hygiene habits, since children tend to be model the attitude of their elders. Adults need to be stimulated, responsive and cooperative and present knowledge, healthy habits and positive attitudes in order to act as multipliers, encouraging and guiding the children to get a proper lifestyle for oral health (Campos et al.). Regarding oral health habits of pregnant women, it was observed that a significant number did not attend the dental clinic during pregnancy and did not have the habit. Another important finding was observed that $94.55 \%$ brush their teeth every day and $75.51 \%$ do so after meals. Good oral hygiene habits are common when health values are accepted as part of the family lifestyle (Costa et al.). 
The influence of sugar or sugary substances on the teeth should be well known theme and solidified in maternal knowledge, because the deficiency in care can result in irreversible damage (deOliveira \& Nadanovsky; Campos et al.; Eigbobo \& Onyeaso). The theme, however, was not evident in more than half of the women's research group, and $57.82 \%$ said ignoring the damage caused by careless intake. In addition, this sample there is a grievance, cause $65.30 \%$ of women indicated to have an income of 1-2 minimum wages. The income is directly related to material conditions, it is important to access to health, influencing the type of food, clothing, housing quality and location, access to knowledge and health care (Geisinger et al.; Shamsi et al.).

When asked about the care provided with the eruption of teeth and the baby's mouth hygiene, $57.82 \%$ and $59.86 \%$ did not know what good practices are. The bottle caries, for example, is a disease that affects babies and is related to the intake of sugary liquid and the lack and / or deficiency of a regular cleaning (Brião).

Fluoride has protective action and great importance for the maintenance of health in the oral cavity, however if administered incorrectly can cause irreversible damage (Campos et al.; Costa et al.). Basic knowledge of fluoride action and the consequences caused by the excessive intake is deficient among women who were surveyed, since $77.55 \%$ did not know the action and $87.75 \%$ were ignorant of the elapsed consumption consequences excess.

The literature asserts that the prevalence of caries in the primary dentition grows in proportion to the child's age. This fact points to the importance of the early attention to oral health (Geisinger et al.; Brião). However, the percentages obtained reveal that $77.55 \%$ of respondents are unaware of the moment they should obtain information about the care of the oral health of the baby.

One way that has a higher prevalence of infection of the oral cavity of the baby is called "vertical transmission." A "vertical transmission" occurs between the exchange's mother fluids, or caregivers for children (Campos et al.). During the interviews, $60.54 \%$ of the women said that they kiss hands, lips and face of the baby. Oral bacteria are transferred by parents to the baby during these acts, colonizing the environment and remaining there. Another way of transmission is cooling the food as they blow, along with the breath exhalation there is an incredible amount of saliva, contaminating food. However, 80.96 $\%$ of women reported using alternative methods to cool food and only $19.04 \%$ blow.

From the foregoing it is observed that the family is the main contributor in developing the creation of correct and healthy habits in children. The example of mothers is essential for their children to acquire good habits. It is therefore important that mothers have sufficient and appropriate knowledge regarding oral health and are motivated and empowered to act in the child's health promotion. Thereby will be able to pass on correct guidance to children, developing good practice and having positive attitudes. The first step to success on building oral hygiene habits in children is the awareness of parents about their educational role (Campos et al.; Costa et al.).

\section{CONCLUSION}

From the mothers interviewed the largest portion does not have enough information on the oral care that they should give to their baby. It was noted also with the family being the main source of transferring habits, as well as information related to the measures to be taken for the prevention of certain diseases. However, it is essential that pregnant women seek professional guidance, since a large number of respondents are ignorant about key issues in maintaining oral health.

NOGUEIRA, B. M. L.; NOGUEIRA, B. C. L.; FONSECA, R. R. S.; BRANDÃO, G. A. M.; MENEZES, T. O. A. \& TEMBRA, D. P. S. Conocimientos y actitudes de las mujeres embarazadas sobre la salud oral. Int. J. Odontostomat., 10(2):297302, 2016.

RESUMEN: Hay evidencia de que los perfiles, hábitos y conocimientos de la salud influyen en la salud oral de los niños. El objetivo de este estudio fue evaluar el conocimiento de las mujeres embarazadas en las prácticas de higiene oral y el cuidado de la cavidad oral del bebé. Una encuesta epidemiológica se llevó a cabo en 147 mujeres embarazadas. La muestra estuvo compuesta predominantemente por mujeres jóvenes, de las cuales el 33,33 \% no había completado la escuela primaria y la mayoría eran amas de casa con ingresos familiares entre 1-2 salarios mínimos. La familia fue considerado el principal medio de transmisión de información sobre la higiene oral.

PALABRAS CLAVE: mujeres embarazadas, higiene oral, niño. 


\section{REFERENCES}

Brião, D. V. O Atendimento Odontológico às Gestantes do Município de Rio Grande, Rio Grande do Sul. Tesis de Grado. Rio Grande do Sul, Universidade Federal do Rio Grande do Sul, Faculdade de Odontologia, 2014.

Campos, L.; Bottan, E. R.; Birolo, J. B.; Silveira, E. G. \& Schimitt, B. H. E. Conhecimento de mães de diferentes classes sociais sobre saúde bucal no município de Cocal do Sul (SC). Rev. Sul-Bras. Odontol., 7(3):287-95, 2010.

Costa, S. M.; Martins, C. C.; Bonfim, M. L.; Zina, L. G.; Paiva, S. M.; Pordeus, I. A. \& Abreu, M. H. A systematic review of socioeconomic indicators and dental caries in adults. Int. J. Environ. Res. Public Health, 9(10):3540-74, 2012.

Eigbobo, J. O. \& Onyeaso, C. O. Maternal knowledge and awareness of factors affecting oral health in the paediatric population. Odontostomatol. Trop., 36(142):15-24, 2013.

Gaffield, M. L.; Gilbert, B. J.; Malvitz, D. M. \& Romaguera, R. Oral health during pregnancy: an analysis of information collected by the pregnancy risk assessment monitoring system. J. Am. Dent. Assoc., 132(7):1009-16, 2001.

Geisinger, M. L.; Geurs, N. C.; Bain, J. L.; Kaur, M.; Vassilopoulos, P. J.; Cliver, S. P.; Hauth, J. C. \& Reddy, M. $S$. Oral health education and therapy reduces gingivitis during pregnancy. J. Clin. Periodontol., 41(2):141-8, 2013.

George, A.; Johnson, M.; Blinkhorn, A.; Ajwani, S.; Bhole, S.; Yeo, A. E. \& Ellis, S. The oral health status, practices and knowledge of pregnant women in south-western Sydney. Aust. Dent. J., 58(1):26-33, 2013.

George, A.; Johnson, M.; Blinkhorn, A.; Ellis, S. \& Ajwani, S. Promoting oral health during pregnancy: current evidence and implications for Australian midwives. J. Clin. Nurs., 19(23-24):3324-33, 2010.

Keirse, M. J. \& Plutzer, K. Women's attitudes to and perceptions of oral health and dental care during pregnancy. J. Perinat. Med., 38(1):3-8, 2010.

Kurien, S.; Kattimani, V. S.; Sriram, R. R.; Sriram, S. K.; Rao, V. K. P.; Bhupathi, A.; Bodduru, R. R. \& Patil, M. N. Management of pregnant patient in dentistry. J. Int. Oral Health, 5(1):88-97, 2013.

Morgan, M. A.; Crall, J.; Goldenberg, R. L. \& Schulkin, J. Oral health during pregnancy. J. Matern. Fetal Neonatal Med., 22(9):733-9, 2009.

de Oliveira, B. H. \& Nadanovsky, P. The impact of oral pain on quality of life during pregnancy in low-income Brazilian women. J. Orofac. Pain, 20(4):297-305, 2006.
Patil, S.; Thakur, R.; K. M.; Paul, S. T. \& Gadicherla, P. Oral health coalition: Knowledge, attitude, practice behaviours among gynaecologists and dental practitioners. J. Int. Oral Health, 5(1):8-15, 2013.

Ramos, G. M. S.; Castro, L. B.; Rocha, C. T. \& Neves, B. G. Pregnant women's knowledge of baby's oral health in a basic health unit, Fortaleza, Brazil. Braz. Res. Pediatr. Dent. Integr. Clin., 14(3):239-48, 2014.

Saddki, N.; Yusoff, A. \& Hwang, Y. L. Factors associated with dental visit and barriers to utilisation of oral health care services in a sample of antenatal mothers in Hospital Universiti Sains Malaysia. B. M. C. Public Health, 10:75, 2010.

Schou, L. \& Uitenbroek, D. Social and behavioural indicators of caries experience in 5-year-old children. Community Dent. Oral Epidemiol., 23(5):276-81, 1995.

Shamsi, M.; Hidarnia, A.; Niknami, S.; Rafiee, M. \& Karimi, M. Oral health during pregnancy: A study from women with pregnancy. Dent. Res. J. (Isfahan), 10(3):409-10, 2013.

Strafford, K. E.; Shellhaas, C. \& Hade, E. M. Provider and patient perceptions about dental care during pregnancy. J. Matern. Fetal Neonatal. Med., 21(1):63-71, 2008.

Yost, J. \& Li, Y. Promoting oral health from birth through childhood: prevention of early childhood caries. M. C. N. Am. J. Matern. Child Nurs., 33(1):17-23, 2008.

Correspondence to:

Dra. Brenna Magdalena Lima Nogueira

Endodontics department

Graduate Program in Clinical Dentistry

Faculty of Dentistry

Federal University of Pará

Belém, PA

BRAZIL

Email: bre_nog@hotmail.com

Received: 17-11-2015

Accepted: 11-03-2016 